\title{
Szkice
}

\section{"Mówić w imieniu biotycznej wspólnoty". Anatomie i teorie tekstu środowiskowego/ ekologicznego}

Aleksandra Ubertowska
NARODOWY PROGRAM

ROZWOJU HUMANISTYK

Artykuł powstał w ramach realizacji projektu

badawczego "Ekopoetyk historycznych katastrof i konfliktów w literaturze polskiej XX i XXI wieku. Perspektywa porównawcza", finansowanego przez Narodowy Program Rozwoju Humanistyki w latach 2016-2019 (nr projektu: $2 \mathrm{aH} 15005683$ )
$\mathbf{W}$ efektownym stwierdzeniu Aldo Leopolda, które zostało przywołane w tytule („chodzi o to, abyśmy wreszcie zaczęli mówić w imieniu biotycznej wspólnoty"1) najbardziej kontrowersyjny punkt wybrzmiewa oczywiście nie tam, gdzie mowa o utopii „ekologicznej społeczności" - znoszącej granice międzygatunkowe, zacierającej antropocentryczne binaryzmy natura-kultura, podmiot-przedmiot - ale w samym wezwaniu do „artykułowania natury”, „mówienia o naturze”, a zatem w postulacie semantyzacji obszaru, który wydaje się surowym, nieredukowalnym zewnętrzem kultury. To zapętlenie poznawcze dobrze określa wyjściową aporię ekokrytyki, nacinającą jej wewnątrzteoretyczną świadomość. Krytyka ekologiczna naznaczona jest źródłową niewspółmiernością, bowiem starając się zbliżyć do istoty natury w tekście, zarazem nieuchronnie się od

1 Cyt. według L. Buell The Future of Environmental Criticism: Environmental Crisis and Literary Imagination, Blackwell Publishing 2005, s. 136 .

\section{Aleksandra} Ubertowska

- literaturoznawczyni, wykładowczyni współczesnej literatury polskiej na Uniwersytecie Gdańskim, obszary jej zainteresowań badawczych to literatura Holocaustu, problematyka tożsamości, ekokrytyka. Swoje artykuły zamieszczała na łamach „Tekstów Drugich”, „Pamiętnika Literackiego”, ,"Ruchu Literackiego", tomów zbiorowych polskich i zagranicznych wydawnictw (m.in. Lexington Books, Peter Lang, Akademie Verlag). 
niej oddala, wyobcowuje poprzez system znaków. Niewiele mogą tu pomóc refiguracje podmiotowości i tekstu, dokonywane w filozofii Bruno Latoura, Gilles'a Deleuze'a, Rosi Braidotti, podejmujące próbę stworzenia nowych narzędzi opisu literatury wobec fenomenu życia i procesów środowiskowych. Sytuację dodatkowo komplikują maksymalistyczne ambicje krytyków ekologicznych, którzy chcą wierzyć w silną performatywność tekstu i metatekstu²; wiarę tę dobrze ilustruje wypowiedź Kena Hiltnera, który z mieszaniną profesjonalnego zaangażowania i naiwnej emfazy określa zadania ekokrytyki jako refleksję nad tym, ,jak akt pisania i uważnego czytania może zbawić planetę?"3.

Być może śladem tej źródłowej niepewności, towarzyszącej narodzinom ekokrytyki jest niestabilność w zakresie pojęciowości, wielość alternatywnych formuł, którymi określa się ten nurt w zakresie literaturoznawstwa. Chodzi tu o formułę-nazwę, która w sposób wyrazisty zaznaczyłaby odrębność ekokrytyki od pokrewnych nurtów czy subdyscyplin, takich jak posthumanizm, humanistyka nieantropocentryczna, ,animal studies”, historia środowiskowa. Oprócz najbardziej powszechnej „ekokrytyki” w badawczym obiegu funkcjonują również takie terminy jak „krytyka środowiskowa” (environmental criticism), „literaturoznawczy eko-dyskurs”, czy „zielone studia filologiczne” (green literary studies). „Małe różnice” nie są pozbawione znaczenia, przeciwnie, to w nich zagnieżdżają się największe poznawcze wyzwania i aporie ekologicznej interpretacji tekstu. Najistotniejsza wydaje się dystynkcja pomiędzy dwoma pierwszymi określeniami. Lawrence Buell, jeden z „ojców założycieli” ekokrytyki, autor fundamentalnej monografii ekologicznej The Environmental Imagination w swoich późnych książkach postuluje zastąpienie wczesnej „krytyki ekologicznej” (ecocriticism) - „literaturoznawstwem środowiskowym" (environmental criticism) i wyprowadzenie

2 Oddziaływanie na ekologiczną świadomość czytelnika jest jednym z celów krytyki środowiskowej, właściwym jej stylem czytania i wartościowania tekstów. Zdaniem Richarda Kerridge'a "fundamentalnym zadaniem ekokrytyki jest ocena tekstów z punktu widzenia troski o środowisko, co pociąga za sobą wprowadzenie kryteriów ekologicznych do debaty o kulturze. [...] Ekokrytykom przyświeca nadzieja, że kryteria ekologiczne staną się pożądanym elementem dyskusji na temat wszystkich odmian literatury i będą znakiem generalnej zmiany w sferze kulturowych wartości i życia codziennego". R. Kerridge Ecocritical Approaches to Literary Form and Genre. Urgency, Depth, Provisionality, Temporality, w: The Oxford Handbook ofEcocriticism, ed. by G. Gerrard, Oxford University Press, Oxford 2014, s. 361.

3 K. Hiltner General Introduction, w: Ecocriticism. The Essential Reader, Routledge, London-New York 2015. 
z tej zamiany daleko idących konsekwencji metodologicznych ${ }^{4}$. „Krytyka środowiskowa", jego zdaniem, znacznie lepiej ujmuje hybrydyczność przedmiotów badań, różnorodność środowisk (nie tylko dzikiej natury, ale także miasta jako „biopolis”), a zatem współwystępowanie komponentów „naturalnych” i „fabrykowanych”, wreszcie akcentuje konieczność otwarcia interdyscyplinarnego, wyważenia proporcji pomiędzy wymogami „warsztatu filologa" a odkryciami klimatologów, biologów, genetyków, historyków środowiskowych.

Istotną właściwością ekokrytyki jest jej laboratoryjny charakter, wyrażający się w porzuceniu aspiracji do zajęcia statusu ustabilizowanej metodologii, dysponującej poręcznym słownikiem terminów i procedur aplikacyjnych. Przeciwnie, literaturoznawstwo ekologiczne unika operacyjnego „domknięcia" (closure), choć jej dorobek i horyzont badawczy znacznie wykracza poza poziom przyczynków, czy niezobowiązujących przybliżeń metodologicznych. Ekokrytyka, zachowując świadomość słabości, płynących z zajmowania „przemocowej" metateoretycznej pozycji, przyznaje sobie jednak, specyficznie pojmowane, prawo do quasi-panoramicznego oglądu cząstkowych analiz literaturoznawczych. Timothy Clark tłumaczy to w sposób następujący: skoro odrzucamy jako naiwne wyobrażenie o autoteliczności kultury, skoro postrzegamy ją jako osadzoną w wielu kontekstach, również w kontekście biosfery, powietrza, wody, życia roślin i zwierząt, to ekokrytyka nieuchronnie staje się „refleksją meta-kontekstualną"5. Rozwijając intuicję badacza, można by powiedzieć, że zadaniem ekokrytyki jest opis uznakowionych powiązań między różnorodnymi bytami, laboratoryjne wypróbowywanie hybrydycznych intertekstowych, interbiotycznych zrostów, katalogowanie nowych biomorficznych bibliotek i archiwów ludzkości.

Najczęściej przywoływane argumenty, uzasadniające konieczność przyznania ekokrytyce istotnej pozycji na mapie współczesnej humanistyki (a nie oszukujmy się - budzi ona rozmaite wątpliwości czy zarzuty natury ideologicznej) nie mają charakteru operacyjnego czy pragmatycznego, wyrastają zaś

4 L. Buell Introduction, w: The Future of Environmental Criticism: Environmental Crisis and Literary Imagination, Blackwell Publishing 2005, S. 5.

5 T. Clark The Cambridge Introduction to Literature and the Environment, Cambridge University Press 2011, s. 4. Dla potrzeb niniejszego artykułu przyjmuję definicję ekokrytyki, sformułowaną w przywoływanej książce Clarka "(ekokrytyka) to badanie relacji między literaturą i środowiskiem naturalnym, zwykle uprawiane z perspektywy aktualnego globalnego kryzysu klimatycznego i wynikającej stąd potrzeby rewizjonizmu, przejawiającego się w potrzebie stworzenia nowych modeli myślenia i literaturoznawczej pragmatyki" (s. XIII). 
z namysłu etycznego, z diagnozy współczesności, również tej, która kształtuje oblicze współczesnego uniwersytetu. Ekokrytyka, dzięki emfatycznemu zaangażowaniu - postawie, którą wymusza zarówno u badacza, jak i wśród studentów, staje się wyzwaniem dla neoliberalnej polityki, która dotarła również do sfery szkolnictwa wyższego i badań naukowych, polityki zdominowanej przez utylitaryzm, ilościowe modele nauki, wymóg rynkowej konkurencyjności'. Dzięki nadwyżce zaangażowanej bezinteresowności, owej wyszydzanej egzaltacji i intelektualnemu ,nawiedzeniu" krytyka środowiskowa może wytyczyć drogi wyjścia poza ciasne, tak doskwierające humanistyce ograniczenia instytucjonalne.

\section{Mapowanie ekokrytycznej biblioteki}

Nic dziwnego zatem, że ekokrytyka (pozostańmy przy tym, najbardziej koncyliacyjnym metodologicznie terminie) wielu badaczom z kręgu humanistyki wydaje się zjawiskiem problematycznym, o zatartych, nieostrych granicach i nie do końca określonym przedmiocie badań. W pierwszym odruchu chciałoby się usytuować ją w pobliżu dyskursów mniejszościowych, które charakteryzuje wyrazisty rys emancypacyjny - ich fundamentalną przesłanką jest udzielenie (w literaturze) głosu podmiotom „subalternalnym”, podrzędnym, podbitym, marginalizowanym lub istnieniom, które obsadzano w pozycji przedmiotu, obiektu, zasobu. Jednak w przeciwieństwie do literaturoznawczego feminizmu, queer/gay/lesbians studies, postkolonializmu czy nawet „animal studies" status owego upodmiotowionego obiektu studiów wydaje się niejasny, słabo uchwytny ${ }^{7}$. Nie jest on osobą, rzeczą, wyizolowanym krajobrazem, ani zwierzęciem, wchodzącym przecież w złożone relacje z człowiekiem. Obiektem środowiskowego namysłu jest bowiem kwestia utekstowienia całej konfiguracji zagadnień: od świata roślin i środowiska naturalnego, ujętego wszakże w szerokiej perspektywie historii ewolucji, poprzez materię i jej przemiany, po procesy, głównie destrukcyjne, zachodzące w atmosferze,

6 Por. H.Zapf Introduction, w: Handbook of Ecocriticism and Cultural Ecology, ed. by H. Zapf, Walter de Gruyter Verlag, Berlin-Boston 2016, s. 1.

7 Warto przytoczyć tu argumenty, zgłoszone przez Cheryll Glotfelty, która uważa, że nieobecność perspektywy środowiskowej we współczesnej nauce o literaturze, która do połowy lat 8o. zajmowała się problemami "gender", etniczności, rasy, tekstu, ale nie świata zewnętrznego, innych, nieludzkich ekosystemów świadczyła o jej nieuleczalnie akademickim charakterze i powierzchowności deklaracji rewizjonistycznych. Zob. Ch. Glotfelty Literary Studies in an Age of Environmental Crisis, w: Ecocoriticism. The Essential Reader, ed. by K. Hiltner, Routledge, London-New York 2015, s. 120. 
zwłaszcza niekorzystne i niezauważalne gołym okiem zmiany klimatu w epoce antropocenu. Nie jest więc wcale takie pewne, czy owe procesy i byty w ogóle zabiegałyby o obsadzenie w roli podmiotu lub nawet jego nieantropomorficznego Latourowskiego ekwiwalentu - „aktanta” (nośnika sprawczości). Bardziej odpowiednie byłoby sformułowanie, że oto „-centryczny”, dośrodkowy, antropomorficzny podmiot lub jego replika zostały w krytyce ekologicznej zastąpione przez subiektywność bardziej mgławicową, rozpyloną w przestrzeni i czasie, rozumianą jako „sieć interakcyjnych materialnych sprawczości” (Karen Barad) czy „transkorporalność” w duchu filozofii Stacy Alaimo.

Ekokrytyka jako nurt literaturoznawstwa ma swoją wewnętrzną dynamikę, którą zwykło się konceptualizować za pomocą biotyczno-akwatycznej metafory „fali” . Za Lawrence'em Buellem przyjmuje się, że wczesne monografie - publikowane od lat 6o., kiedy to stworzono formułę „ekokrytyki”, do lat 9o. ubiegłego wieku - ustanowiły „p i e r w s z ą fal ę" ekokrytyki. Refleksja badawcza Leo Marxa, Lawrence'a Buella, Jonathana Bate'a koncentrowała się wówczas wokół ekologicznego wymiaru przestrzeni, idei wilderness/dzikiej, nieujarzmione natury („dziczy”) i pastoralności jako utopijnej estetyki harmonijnego współegzystowania ze środowiskiem. Ekokrytyka pierwszej fali bazowała na materiale, zaczerpniętym z amerykańskiej (czasami również angielskiej) literatury; kanon tekstów przez nią stworzony i eksplorowany w badawczej praktyce obejmował dzieła H.D. Thoreau (Walden), Johna Muira, J.F. Coopera, Rachel Carson, aż po współczesne dystopie, takie jak Droga Cormana McCarthy'ego. Znamiennym rysem wczesnej ekokrytyki jest również „czytanie retrospektywne”, środowiskowa relektura dzieł czasami odległych w czasie, jak epos o Gilgameszu ${ }^{10}$ czy dramaty Szekspira ${ }^{11}$.

Druga fala piśmiennictwa ekokrytycznego wyłania się na przełomie wieku XX i XXI, wraz z rozpowszechnieniem badań kulturowych i konstruktywizmu jako optyki interdyscyplinarnej, ekofeminizmu, badań

8 Zob. K. Hiltner First-Wave Ecocriticism; Second-Wave Ecocriticism, w: Ecocriticism. The Essential Reader.

9 Udanymi próbami zastosowania na polskim gruncie założeń wczesnej ekokrytyki są książki Justyny Tabaszewskiej Jedna przyroda czy przyrody alternatywne? O pojmowaniu i obrazach przyrody w polskiej poezji, Universitas, Kraków 2010 i Julii Fiedorczuk Cyborg w ogrodzie. Wprowadzenie do ekokrytyki, Wydawnictwo Naukowe Katedra, Gdańsk 2015. Zob. K. Hiltner General Introduction, w: Ecocriticism. The Essential Reader, s. 1.

11 Zob. L. Marx Shakespeare's American Fable, w: Ecocriticism. The Essential Reader; G. Egan Green Shakespeare. From ecopolitics to ecocriticism, Routledge, London-New York 2006. 
postkolonialnych, które doprowadziły do rozszczelnienia dotychczasowego, głównie anglosaskiego kanonu literatury środowiskowej ${ }^{12}$. Poszerzeniu uległ również zakres znaczeniowy natury - obiektem badań staje się środowisko, otaczające człowieka, w tym również miasto jako „druga natura”, badane wszakże najczęściej w kontekście zjawisk przyrodniczych, zanieczyszczenia powietrza, ekspansji cywilizacji, dokonującej się kosztem ekologicznych przestrzeni liminalnych (plaży, bagien, prastarych puszcz).

W tej fazie dochodzi do znaczących rekonceptualizacji wczesnej krytyki środowiskowej. Założenia poetyki ekokrytycznej pierwszej fali są tu podważane z pozycji studiów kulturowych i etnicznych. Z tej perspektywy pastoralizm - topos ekokrytyczny z okresu założycielskiego - jawi się jako estetyka „białych, uprzywilejowanych mężczyzn”, której podstaw nie musiały podzielać wszystkie podmioty historii. Jak przekonująco pokazuje Michael Bennett w swoim artykule Anti-Pastoralism, Frederick Douglass, and the Nature of Slavery ${ }^{13}$, była to estetyka ufundowana na ekskluzji, rasistowskim ostracyzmie i wyzysku ekonomicznym, nic zatem dziwnego, że w tradycji kultury Afroamerykanów utrwalił się raczej rys antypastoralny ${ }^{14}$, wyraźnie wyczuwalny w prozie Toni Morrison czy słynnej piosence Strange Fruit Billie Holliday.

Część literaturoznawców wyróżnia także trzecią i (budzącą największe kontrowersje) czwartą falę krytyki środowiskowej ${ }^{15}$. Ekokrytyka tr z e ciej fali zaznacza swoją obecność w pierwszej dekadzie XXI wieku i to ona w znacznym stopniu wytyczyła aktualny horyzont poszukiwań w tym obszarze. Najistotniejszą przemianą, jaka się wówczas dokonała, było wykształcenie ponadnarodowej, globalnej perspektywy, przekraczającej

Szczególnie szeroko reprezentowane w tym obszarze są tzw. zielone studia postkolonialne; zob. m.in. Postcolonial Ecologies. Literatures of the Environment, ed. by E. De Loughney, G.B. Handley, Oxford University Press, Oxford 2011; R. Nixon Environmentalism and Postcolonialism, w: Postcolonial Studies and Beyond, ed. by A. Loomba i in., Duke University Press 2005. M. Bennett Anti-Pastoralism, Frederick Douglass, and the Nature of Slavery, w: Beyond Nature Writing. Expanding the Boundaries of Ecocriticism, ed. by K. Armbuster, K.R. Wallace, University Press of Virginia, Charlottesville-London 2001.

14 W podobnej funkcji występują odwołania do estetyki pastoralnej w literaturze postkolonialnej, która łączy podbój terytorium krajów afrykańskich, Indii, Australii z destrukcją krajobrazu (powieści Amitav Gosh, Ken Saro Wiwy, Arundhat Roy). Wiąże się to z pojawieniem się „zielonego postkolonializmu”, , "krytyki środowiskowej biednego Południa" który od początku pozostawał w stanie głębokiego konfliktu wobec amerykańskiej i europejskiej ekokrytyki wczesnej fazy. Zob. G. Huggan, H. Tiffin Postcolonial Ecocriticism. Literature, Animals, Environment, Routledge, New York 2010. 
granice kultur i (ekologicznych) mitografii narodowych. Choć nadal napięcie między globalizmem a bioregionalizmem wytycza jedną z osi refleksji ekokrytycznej ${ }^{16}$, zasadnicze punkty orientacyjne wyznaczają zjawiska antropocenu, zmian klimatycznych, zaniku bioróżnorodności, ekologicznej sprawiedliwości, rozmaicie rozwijana teoria społeczeństwa ryzyka (risk society) Ulricha Becka. W sferze metodologii przemiany te ujawniają się w silnej obecności ujęć komparatystycznych i interdyscyplinarnych. To wówczas ekokrytyka staje się siecią badawczą, na której niejako zaszczepiają się nurty i subdyscypliny bardzo eksperymentatorskie, pozornie oddalone od tradycyjnej problematyki natury, by wskazać ekologiczną analizę narracji afektywnych Alexy Weik von Mossner, skupioną wokół sensualnych krajobrazów Oklahomy w Gronach gniewu J. Steinbecka" ${ }^{17}$, włączanie w obręb ekokrytyki pewnych komponentów, zaczerpniętych z "memory studies” (artykuły Christophera Schliephake'a) ${ }^{18}$ czy nowatorskie, bardzo inspirujące próby aplikacji teorii traumy do badań ekologicznych, podejmowane przez Katharinę Donn ${ }^{19}$. Literaturoznawstwo ekokrytyczne staje się wówczas centrum, rdzeniem metodologicznym, promieniującym na inne specjalizacje z zakresu historii sztuki; powstają ekokrytyczna muzykologia ${ }^{20}$, filmoznawstwo ${ }^{21}$, analiza sztuk wizualnych ${ }^{22}$, gier komputerowych ${ }^{23}$.

16 Świadczy o tym wielość tomów zbiorowych i monografii autorskich o wyraźnie lokalnym, etnicznym zabarwieniu, badająca obecność motywów czy narracji ekologicznych w literaturach narodowych albo zbierająca artykuły ekokrytyków z określonych krajów. Por. L. Gairn Ecology and Modern Scottish Literature, Edinbourgh University Press 2008; E. Flannery Ireland and Ecocriticism. Literature, History, and Environental Justice, Routledge, New York 2016; S. lovino Ecocriticism and Italy: Ecology, Resistance and Liberation, Bloomsbury Academic 2016.

17 A. Weik von Mossner Environmental Narrative, Embodiment, and Emotion, w: Handbook of Ecocriticism...

Ch. Schliepshake Memory, Place, and Ecology in the Contemporary American Novel, w: Literature, Ecology, Ethics. Recent Trends in the Ecocriticism, ed. by T. Mueller, M. Sauter, Universitaetsverlag Winter, Heidelberg 2012.

19 K. Donn Beyond the Wasteland. An Ecocritical Reading of Modernist Trauma Literature, w: Handbook of Ecocriticsm...

Zob. A.S. Allen Ecomusicology: From Poetics to Practice, w: Handbook of Ecocriticism... Zob. S. MacDonald PANORAMA: the Ecocinematic Territories, w: Handbook of Ecocriticism...

Zob. S. Boettger Within and Beyond the Art World: Environmental Criticism of Visual Art, w: Handbook of Ecocriticism...; M. Bakke Bio-transfiguracje. Sztuka i estetyka posthumanizmu, Poznań 2010.

23 H. Lewis Ulman Beyond Nature/Writing. Virtual Landscapes Online, in Print, and in "Real Life", w: Beyond Nature Writing. 
Ekokrytyka trzeciej fali porzuca jednostronnie rozumianą poetykę „nowego realizmu" z wcześniejszych dekad i śmielej wchłania, częściowo z sobą sprzeczne, inspiracje płynące ze strony poststrukturalizmu. Serpil Oppermann w ważnym artykule ${ }^{24}$, podejmującym karkołomne wyzwanie odnalezienia wspólnej płaszczyzny dla ekokrytyki i postmodernizmu, stwierdza, że w gruncie rzeczy spór pomiędzy nimi jest pozorny, ponieważ obie dyscypliny oświetlają się wzajemnie, wydobywając utajone lub niedoczytane treści: postmodernizm nie podważa realności świata pozatekstowego, a jedynie samoczywistość jego reprezentacji, krytyka środowiskowa zaś w istocie nie dociera do natury „samej w sobie”, eksplorując wyobraźniowe strategie i artefakty, donoszące się do interakcji z materialnym, ucieleśnionym środowiskiem. Głównym źródłem inspiracji w trzeciej fazie ekokrytyki stają się dzieła Gilles'a Deleuze'a i wizja nowego witalizmu, rozwijana przez Rosi Braidotti.

Znamiennym przykładem ekokrytyki trzeciej fali wydaje się monografia Timothy Clarka Ecocriticism on the Edge. Anthropocene as a Threshold Concept $(2015)^{25}$. Epoka antropocenu - w której wpływ człowieka na biosferę po raz pierwszy w historii przewyższył stopień oddziaływania natury na świat ludzki - w ujęciu Clarka pozwala się scharakteryzować najtrafniej za pomocą kategorii „zaburzenia” (disorder), „niewspółmierności”, „zachwiania równowagi”, dezorientacji, ujawniającej się na poziomie myśli i języka. Ikoną antropocenu jest w powszechnym odczuciu zdjęcie globu ziemskiego, wykonane ze statku kosmicznego „Apollo" w roku 1968; konfrontuje nas ono z zasadniczą obcością perspektyw: ludzkiej i planetarnej, globalnej, wymuszając zarazem nowy styl czytania, który uchwyciłby „terrastrialność”, nieredukowalną zdarzeniowość ziemi, zacieraną przez zmediatyzowane przekazy, również literackie. Chodzi o to, by rozpoznać "planetę ziemię jako ludzkie archiwum, fundament kulturowej pamięci, kruchą materialną matrycę wszystkich kulturowych inskrypcji i samo-odniesień człowieka”26. Terrastrialność to „koncept graniczny", oddający istotę życia na Ziemi - biologiczną przygodność i nieprzewidywalność wydarzeń klimatycznych, charakterystycznych dla epoki antropocenu. Figurą kluczową, poetyckim ekwiwalentem takiego światopoglądu staje się w ujęciu Timothy Clarka katachreza, wadliwa, ułomna metafora lub

S. Oppermann Rethinking Ecocriticism in an Ecological Postmodern Framework: Mangled Matter, Meaning, and Agency, w: Literature, Ecology, Ethics.

T. Clark Ecocriticism on the Edge. Anthropocene as a Threshold Concept, Bloomsbury Academia, London-New York 2015. 
porównanie, których występowanie tropi amerykański autor w - odczytanej jako protoekologiczna - poezji Johna Keatsa i Williama Wordswortha. To w niej wyraża się proces „rozregulowania decorum”, który należałoby postrzegać jako odpowiedź na destrukcję planety i rozchwiania równowagi klimatycznej.

\section{Jak oddać niestabilność bioform?}

Dynamika historii ekokrytyki, ujęta w ramy trzech „fal”, mimo sugestii następowania po sobie kolejnych faz, nie zakłada oświeceniowego progresywizmu, zasady przezwyciężenia (i porzucania) starych, niedoskonałych formacji naukowych i zastępowania ich przez propozycje nowe. Aktywność wielu badaczy przekracza podziały czasowe, są postacie publikujące na przestrzeni dwóch czy trzech „fal” (jak Buell czy Glosfelty). Dominująca, choć nieco utajoną, zasadą jest raczej nawarstwianie się konceptów z różnych faz (i zarazem ich wzajemne na sobie pasożytowanie), regułą wydaje się również zaskakująca trwałość badawczych koncepcji z wczesnych „fal” ekokrytycznych.

I tak np. Foucaultowskie ujmowanie motywów natury jako elementów kolonialnej „wiedzy-władzy”, tak charakterystyczne dla trzeciej fali krytyki ekologicznej, było już przecież obecne we wczesnych monografiach Davida Mazela ${ }^{27}$ i Michaela Brysona ${ }^{28}$, którzy analizowali pozycję motywu wilderness w narodowej amerykańskiej narracji podboju, uzasadniającej zawłaszczanie zachodnich terenów Ameryki Północnej „uczuciem lęku przed byciem otoczonym przez dzikość" ${ }^{29}$. Ten tryb myślenia znajdzie przedłużenie w ramach postkolonialnej ekokrytyki, uprawianej intensywnie w ostatnich dekadach. Ideę, wedle której motyw natury byłby metaforą, konceptualizującą istotne procesy historyczne, podejmuje choćby Upamanyu Pablo Mukherjee ${ }^{30}$, który w swoim eseju o motywach epidemii cholery w prozie Rudyarda Kiplinga pokazuje, że patogeny, chorobotwórcze wirusy służyły jako ideologiczne przekazy, wykorzystywane w dyskursach imperialnych. W opowiadaniach Kiplinga (Thrown Away, By Word of Mouth) sekwencja wybuchu epidemii ma

27 D. Mazel American Literary Environmentalism, The University of Georgia Press, Athens-London 2000.

M.A. Bryson, Visions of the Land. Science, Literature, and the American Environment from the Era of Exploration to the Age of Ecology, University Press of Virginia, London 2002.

D. Mazel American Literary..., s. 35. 
walor formacyjny, wprawiający w ruch narrację i zarazem wytyczający kierunek wartościowania kultury i ludności Indii. Dzięki wsparciu „miękkiej siły" literackich opowieści imperialna biowładza mogła konstruować moralne uzasadnienia podboju krajobrazu, który już zawsze będzie jawił się jako „zarażony”, ulegający degeneracji, domagający się interwencji „oświeconej” zachodniej medycyny, a zatem wkroczenia "paliatywnego imperializmu”.

Jednak najbardziej chyba inspirującą koncepcją, sformułowaną w ramach pierwszej fazy ekokrytyki, która w moim odczuciu nadal zachowuje zdolność aplikacyjną, jest zarys „t e k s t u ś r o d o w i s k o w e go” (environmental text) Lawrence'a Buella, sformułowany w jego pierwszej, przywoływanej już, książce The Environmental Imagination. Thoreau, Nature, Writing, and the Formation of American Culture (1995). Jest to koncepcja ponadczasowa, ponieważ pytanie o to, co czyni tekst ekologicznym, nadal rozpala umysły ekokrytyków ${ }^{31}$, a odpowiedź na nie udzielona lokuje badacza w określonym horyzoncie epistemicznym, decyduje o jego naukowej tożsamości. Kwestią fundamentalną, założycielską, która wyznacza poziom refleksji metatekstowej i metadyscyplinarnej pozostaje nieustannie pytanie o naturę „sądu ekokrytycznego" (jak to ujął Richard Kerridge ${ }^{32}$ ), o warunkujące go ufundowania czy też może właśnie ich znaczący brak, przerzucający na krytyka odpowiedzialność za jego prawomocność.

Lawrence Buell, kreśląc zarysy „tekstu środowiskowego”, rozwija wprawdzie zasadniczą przesłankę wczesnej ekokrytyki, przyjmując, że najważniejszym faktem w historii Ameryki była ekologiczna kolonizacja kontynentu poprzez ekstensywną kulturę agrarną wielkich plantacji i choroby, które zdziesiątkowały ludność tubylczą. Estetyką, która pełniła funkcję kompensacyjną wobec agresywnej historii kolonizacji, był pastoralizm. Uważam, że pomimo wyraźnego, przejawiającego się w owych przesłankach, amerykanocentryzmu koncepcja metodologiczna, którą wypracował Buell ma jednak wymiar uniwersalny i pozwala się zastosować poza kontekstem amerykańskim.

Buell w swojej teorii "tekstu środowiskowego" wykracza znacznie poza ograniczenia wczesnej ekokrytyki, która uzasadnienia dla literatury ekologicznej poszukiwała głównie wśród kryteriów tematycznych, motywów, toposów. Amerykański badacz traktuje tekst literacki jako twór niemal organiczny, poszukując w nim również formalnych i materiałowych ekwiwalentów świata

31 Pytanie to pojawia się w wyróżnionym miejscu artykułu wstępnego do ważnego tomu, poświęconego tendencjom rozwojowym ekokrytyki, zob. T. Mueller, M. Sauter Introduction: Ecocritical Extensions, w: Literature, Ecology, Ethics. 
natury. W rozumieniu Buella „tekst środowiskowy” byłby kombinacją kilku właściwości, które sytuowałyby się na przecięciu komponentów wewnątrztekstowych, sytuacji komunikacyjnej i różnorodnych kontekstów kulturowych. Wczesny schemat ,tekstu środowiskowego", zarysowany w pierwszej ekokrytycznej książce Buella, był modyfikowany, opatrywany objaśnieniami czy korektami, zwłaszcza w książce The Future of Environmental Criticism: Environmental Crisis and Literary Imagination (2005), co sprawia, że należy go traktować jako model o zaledwie zarysowanych konturach quasi-gatunkowych $i$ „polach operacyjnych" do wypełnienia. Jest to pewnego rodzaju „skrypt”, draft, zakładający możliwość uzupełnień, inskrypcji, rozwinięć, z której zamierzam tu skorzystać, wskazując na analogię do ujęć innych ekokrytyków. Innymi słowy, koncepcję "tekstu środowiskowego" Lawrence’a Buella można potraktować jako swoisty schemat, siatkę teoretyczną, która - rozbudowywana w głąb, poprzez „zaczepianie" o nią późniejszych w czasie kontynuacji - zmienia swój status, przechodzi z poziomu diachronii na poziom synchronicznego opisania rozwoju interesujących mnie tu zjawisk literaturoznawczych.

1. Po pierwsze, $w$ tekście środowiskowym natura nie powinna być jedynie tłem, środkiem stylistycznym lub ramą przedstawienia, lecz istotną determinantą literackiej fabuły i kondycji postaci. Nadrzędnym przeświadczeniem, którego uszczegółowieniem byłaby konstrukcja tekstu powinno być przekonanie, że ludzka historia jest zawsze generowana przez historię naturalną.

2. Tekst środowiskowy to przekaz, w którym ludzki punkt widzenia i wynikająca z niego struktura interesu ekonomicznego nie jest jedyną uprawnioną perspektywą. Uprzywilejowanym wymiarem tekstu ekologicznego jest orientacja etyczna wypowiedzi; jego istotną częścią powinna być kwestia ludzkiej odpowiedzialności za stan środowiska. Dlatego też miarą wartości tekstu staje się zdolność do prze-kierowania stosunku czytelnika do natury poprzez niepokojące, destabilizujące strategie opowieści, których przykładem mogą być Silent Spring Rachel Carson, ale też Żarłoczny przypływ Amitav Gosh czy Umiłowana Toni Morrison. Wybitne teksty środowiskowe są więc zaprzeczeniem wypowiedzi ideologicznych (ekokrytyka jest wszak oskarżana o indoktrynowanie czytelników w duchu New Age); przeciwnie, ich celem jest raczej poznawcza "dyslokacja” czytelnika, a nie ulokowanie go w bezpiecznej intelektualnie pozycji.

W podobnej, etycznie motywowanej strategii rozmontowywania ustalonych ram komunikacyjnych należałoby usytuować osobliwy gatunek czy 
typ pisania naukowego, który wyłonił się w ramach ekokrytyki, zwany „narrative scholarship". Są to na wpół autobiograficzne artykuły ekokrytyczne, ujawniające uwikłanie badacza literatury (i jego środowiskowego otoczenia) w opisywane warunki klimatyczne czy krajobrazowe. Taki charakter ma monografia Roda Gibletta Cities and Wetlands. The Return of the Repressed in Nature and Culture, której autor przyznaje, że jego fascynacja bagnami ma swoje źródło w dzieciństwie, spędzonym obok podmokłych terenów Luizjany, czy też artykuł Roba Nixona o plaży jako przestrzeni liminalnej33 (również zakorzeniony w biograficznych doświadczeniach autora).

3. Buell silnie akcentuje inkluzywne rozumienie „środowiskowości/ekologiczności" jako (potencjalnej) właściwości każdego tekstu i szerzej, kulturowego artefaktu. Tekst jest traktowany jako świat, cechą dystynktywną tekstu środowiskowego jest „światotwórstwo” (world-making), czego najbardziej znamiennym przykładem wydają się „fikcje spekulatywne”, ekologiczne utopie i dystopie (Diuna Franka Herberta, Droga C. Mc Carthy'ego), które wyzyskują zdolność do wymyślania całego, oryginalnego świata (np. po zniszczeniu planety).

Rozwinięciem tych wątków na nieco innych zasadach wydaje się pojęcie „ekologii kulturowej” Huberta Zapfa, niemieckiego ekokrytyka trzeciej i czwartej fali, autora często komentowanej książki Literatur als kulturelle Oekologie: Zur kulturellen Funktion der imaginaren Texte an Beispielen des amerikanischen Romans (2012). Ambicje poznawcze Zapfa zakładają wywikłanie się z dwóch pułapek: antropocentryzmu, ale również pewnej formy środowiskowego fundamentalizmu czy ekologicznego naturalizmu w filozofii i sztuce (czyli roztopienia kultury w naturze). Teoria Zapfa dowartościowuje literaturę, która w reprezentowanej przez niego optyce staje się swoiście rozumianą „ekologią" kultury i cywilizacji. Dzięki autorefleksyjności, potencjałowi rewizjonistycznemu i sensorium, jakim dysponuje może ona funkcjonować jako narzędzie krytyczne, sygnalizujące niebezpieczeństwa, patologie, nierównowagi w rozwoju planety ${ }^{34}$. Jest przeciwdyskursem krytycznym kultury postindustrialnej, kompensującym brak wyrugowanych ze współczesności

Zob. R. Giblett Cities and Wetlands. The Return of the Repressed in Nature and Culture, Bloomsbury, London-New York 2016; R. Nixon Barrier Beach, w: The Oxford Handbook of Ecocriticism.

$34 \mathrm{H}$. Zapf Cultural Ecology of Literature - Literature as Cultural Ecology, w: Handbook of Ecocriticism... Por. także T. Clark Ecopoetry, w: tegoż The Cambridge Introduction to Literature and the Environment, Cambridge University Press, Cambridge 2012, s. 153. 
języków i możliwości manifestowania oporu wobec niepokojących zmian w historii świata.

4. Tekst środowiskowy ukazuje człowieka w ścisłym związku z przestrzenią, dlatego też narracja rozwija się tu między biegunami „miejsca i wykorzenienia", bioregionalizmu i perspektywy planetarnej. Jednak przeważa dynamiczne ujmowanie jakości spacjalnych, przejawiające się w uprzywilejowaniu literatury podróżniczej i „perypatetycznej”, w której spacer, wędrówka, podróż stają się narracyjną strukturą zapisu relacji ze środowiskiem. Już w Walden Thoreau, jak zauważa Buell, statyczne miejsce zaczyna przekształcać się w sieć „zmiennych kognitywnych profili i perspektyw” ${ }^{35}$; można zatem powiedzieć, że tekst środowiskowy to „rodzaj tekstu, który wyłania się z interakcji kartograficznej wiedzy z eksperymentowaniem ze znaczeniem konkretnego miejsca" ${ }^{\text {"36. }}$.

5. Tekst środowiskowy operuje swoistym chronotopem - dynamiczna przestrzeń występuje tu wespół z czasowością pór roku, czasem naturalnych podziałów i przemian ${ }^{37}$. Stąd wysoka w kanonie ekokrytycznym pozycja takich gatunków jak kronika, kalendarz, powieści lub relacje autobiograficzne, których kompozycja wyznaczana jest przez rytm pór roku (mimowolnie nasuwają się tu skojarzenia z Rokiem myśliwego Czesława Miłosza, Druga jesienia i Wiosna Brunona Schulza).

6. Istotnym problemem, który ma daleko idące konsekwencje dla kształtu formalnego tekstu środowiskowego wydaje się kwestia redefinicji podmiotu, „jaźni” w kategoriach środowiskowych. Sposób pojmowania człowieka jako bytu, „zajmującego jedną z nisz w sieci interaktywnych «bios»"38 sprawia, że w konsekwencji literatura środowiskowa osłabia albo wręcz neguje pozycję postaci i kompetencje osobowego narratora, traktowane jako przywilej antropocentrycznie rozumianej jaźni. Buell zaleca tu motywowaną etycznie postawę i estetykę samoograniczenia, samowyrzeczenia („the aesthetics of

L. Buell The Environmental Imagination..., s. 266.

Tamże, s 280.

Zob. L. Buell The Seasons as a Discipline in Environmental Awareness, w: tegoż The Environmental Imagination, s. 249.

L. Buell The Environmental Imagination..., s. 167. 
relinquishment"39), podporządkowującą roszczenia ludzkiego ,ja” procesom środowiskowym.

Ogólnie można jednak powiedzieć, że podmiot przeżywa swój wielki powrót w ekokrytyce, po przepracowaniu lekcji Bruno Latoura i jego koncepcji ponadgatunkowej sprawczości. Właśnie kontekst literatury (środowiskowej) uwydatnia - jednak - niezbywalność instancji podmiotu, która wszakże ulega zasadniczym przekształceniom. Przede wszystkim, staje się instancją przechodnią, nadbudowaną nad niegdysiejszym binaryzmem podmiot-przedmiot; warto tu zacytować sugestywną wypowiedź Grega Garrarda, który powiada, że dzisiaj istotne jest nie tylko „to jak my piszemy środowisko naturalne, ale i to, jak środowisko pisze nas" ${ }^{\prime 4}$. Podmiot staje się bardziej materialny, „uświatowiony”, immersywny, istnieje w ruchu, łączy dyspozycje krytyczne, kognitywne z afektywnymi i „uczestniczącymi”. Zawsze jednak wraca do tekstu, pytając o to, co z owej proteuszowej kondycji (i na jakich zasadach) może zostać ocalone w artystycznej reprezentacji.

7. Ekokrytyka porzuca zainteresowanie powieścią psychologiczną, literaturą kontemplacyjną, poezją parnasistowską, ego-centryczną lub też proponuje ich bardzo niekanoniczne odczytania. Wysoko lokuje zaś gatunki operujące silną asercją, "odśrodkowe" w swoim zainteresowaniu światem pozatekstowym, charakteryzujące się odpowiedzialnością za sferę przedmiotową opisu. Przede wszystkim „nature writing” (przyrodopisarstwo), którego najsłynniejszym przykładem jest Walden Thoreau - forma tekstowa o paranaukowym charakterze i wyeksponowanym poziomie referencji, odnoszącym się do świata zewnętrznego (lecz nieuchylającym pozostałych poziomów odniesień intertekstualnych, autotelicznych, architekstualnych itp.). Równocześnie „opisywanie natury” zawiera silny komponent medytacyjny i rapsodyczny, z mocno istniejącym ,ja" narratora, którego wrażliwość filtruje doznania natury. Nie jest jednak tak, że krytyka środowiskowa forsuje redukcjonistyczny model „mimesis” jako pewnej utopii radykalnej bezpośredniości i jest z zasady wroga wyrafinowanym konceptom teoretycznym w duchu poststrukturalizmu. Już Lawrence Buell formułuje teoretyczny postulat „ekstraspekcji” jako rewersu „introspekcji”, rysu, charakterystycznego dla literatury mieszczańskiej, z okresu triumfującego antropocentryzmu. Ekstraspekcja to postawa „wglądu w naturę, świat zewnętrzny”, czyli przekierowanie energii

Tamże, s. 156. 
solipsystycznej, którą żywiła się literatura modernizmu na - tylko pozornie - samooczywisty, "toporny poznawczo” świat pozatekstowy. Ekstraspekcja jest jednak wyrafinowaną strategią, konstruowaniem „wglądu w świat”, a nie naiwnym powtórzeniem realizmu jako odzwierciedlenia.

Wysoko w hierarchii form wypowiedzi sytuowana jest poezja, jednak jedynie wybranych poetów, których twórczość wchodzi w intrygujące interakcje ze środowiskiem naturalnym (Wordsworth, Sylvia Plath, i zwłaszcza Derek Wallcott jako poeta amerykański osadzony w pamięci o egzotycznych karaibskich pejzażach). Wokół poezji, poetyckości powstały interesujące koncepcje teoretycznoliterackie, wiążące język poetycki ze światem natury. Scott Knickerbocker w swojej książce Ecopoetics. The Language of Nature, the Nature of Language ${ }^{41}$ zrywa z przeświadczeniem, właściwym ekokrytyce pierwszej fali, głoszącym, że poststrukturalistyczny zwrot ku tekstowi, tekstualności był z gruntu antropocentryczny (podczas gdy kultury oralne, ,fonocentryczne" uważane były za bardziej pokrewne naturze). Knickerbocker, analizując wiersze Wallace'a Stevensa, Elisabeth Bishop, Sylvii Plath pokazuje, że język poetycki w skondensowanej formie ujawnia cechy języka, zbliżające go do żywiołów natury: „dzikość”, nieprzewidywalność, autonomiczność. Krytyk w sposób przekonujący dowodzi słuszności swojej podstawowej tezy głoszącej, że to nie wiersz wolny, ale wiersz tradycyjny (o regularnym metrum, rymowany) odzwierciedla ontologię natury: splot porządku i przygodności, wzoru i inwencji. Właśnie język poetycki byłby zatem materializacją postulowanej przez Buella „eco-speak”, ,green-speak”.

8. Jak więc przedstawiałaby się, zasygnalizowana w jednym z poprzednich akapitów, kwestia domniemanej „organiczności” tekstów środowiskowych, izomorficznej odpowiedniości przekazu i bioform? Jedną z odpowiedzi na to pytanie jest teoria „organicznego formalizmu" Knickerbockera, wprowadzona w zakończeniu wspomnianej wcześniej monografii, zakładająca, że natura, z którą obcujemy jest jednocześnie realna i sfabrykowana, ujęta w ramy kultury (jak powiada Knickerbocker, „im bardziej zbliżamy się do natury, tym bardziej metaforyczne staje się nasze doświadczenie" ${ }^{\text {42 }}$ ). Z kolei w ujęciu Lawrence'a Buella zasadniczą cechą tekstu ekologicznego jest procesualność, płynność, przejawiająca się choćby w metaforyce akwatycznej,

41 S. Knickerbocker Ecopoetics. The Language of Nature, the Nature of Language, Amherst, Boston 2012. 
a ta z kolei ujmowana jest jako część bardziej generalnej cechy, którą krytyk określa jako „niestabilność bioform”, zdolność materii do nieustannej przemiany. Nielinearność życia odzwierciedla nielinearna narracja, złożona z nieciągłych sekwencji, fragmentarycznych „cięć", mikroesejów czy seansów kontemplowania natury.

Fascynacja żywiołami akwatycznymi wielokrotnie dochodzi do głosu w pisarstwie ekokrytycznym, służąc często jako platforma rozważań nad kondycją podmiotu, narratora, materii tekstowej. W eseju Stacy Alaimo ${ }^{43}$ ocean jest we współczesnej kulturze ekosystemem, skupiającym wyparte pragnienia, lęki, fantazmaty zdobywcze, dla których coraz mniej pozostaje obszarów do podboju. Ocean, bohater filmu Jamesa Camerona Aliens of the Deep, wydaje się zarazem wehikułem współczesnej konkwisty, obszarem naukowej eksploracji i kontroli, jak i nową przestrzenią bukoliczną, sprzyjającą kontemplacji. Nade wszystko jednak ocean staje się w refleksji Alaimo metaforą ucieleśnionego podmiotu, który jest efektem materialno-semiotycznego zanurzenia w świecie (material-semiotic immersion), istnienia w wielu sieciach politycznych, biologicznych, biosemiotycznych.

Właśnie biosemiotyka - najbardziej żywotnie rozwijający się nurt krytyki środowiskowej - ujmuje kwestię „organiczności” tekstu literackiego w sposób najbardziej radykalny, niejako odwracając kierunek myślenia Scotta Knickerbockera. Teraz już nie poezja bywa odwzorowaniem procesów, zachodzących w naturze - z perspektywy biosemiotycznej, zainspirowanej filozofią szkoły z Tartu i późnymi pismami Maurice'a Merleau-Ponty'ego, wszystkie byty (idee, ale również mikroby, rośliny, zwierzęta, czynniki klimatyczne) są obiektami znaczącymi, symptomami szerszej semiozy. Jak pisze Wendy Wheeler, cała natura to "biosemiotyczna rozmowa" ${ }^{44}$, a biosfera jest w istocie semiosferą. Kate Rigby, ekokrytyczka specjalizująca się w literaturze romantycznej szuka źródeł takiego myślenia w ideach Natur-Sprache Jakuba Boehme i romantycznej wrażliwości na korespondencje pomiędzy różnymi obszarami istnienia. Zdaniem Rigby, od czasów romantyzmu istnieje w poezji europejskiej „czerwona nitka” biosemiotycznej refleksji, która zakłada, że natura to „nieustanne procesy rekompozycji, dekompozycji, nawiązywania połączeń

S. Alaimo Feminist Science Studies and Ecocriticism. Aesthetics and Entaglement in the Deep Sea, w: The Oxford Handbook of Ecocriticism.

44 W. Wheeler The Lightest Burden: The Aesthetic Abduction of Biosemiotics, w: Handbook of Ecocriticism and Cultural Ecology, s. 29. 
pomiędzy formami życia [...] natura jest napędzana przez semiozę, a funkcję semów pełnią dźwięki, zapachy, ruch, ciężar, faktura, smak, kształt"45.

\section{Materializm, dark ecology, hiperobiekty. C z wa r t a fa la ekokrytyki}

Wydaje się, że ekokrytyka staje się najbardziej twórcza, intelektualnie produktywna tam, gdzie zawiązuje sojusz (lub, przeciwnie - konstruktywny konflikt) z innymi, podobnie nieustabilizowanymi nurtami czy metodologiami współczesnej humanistyki: myślą postkolonialną, teorią systemów, poszukiwaniami w duchu queer, korporalnym witalizmem. Można odnieść wrażenie, że dochodzi tu do pomnożenia sił subwersywnych, wzajemnej mobilizacji potencjałów badawczych, które owocują propozycjami odkrywczymi, współbrzmiącymi z problemami współczesności, i zarazem pozwalającymi zastosować się w praktyce badawczej.

W znacznym stopniu powyższe warunki zostały spełnione w nurtach tzw. c zwartej fali ekokrytyki. To tutaj literaturoznawstwo ekologiczne dociera do krawędzi horyzontu, który sobie w poprzednich okresach nakreśliło, i z tej pozycji prowadzi dyskurs w znacznej mierze metadyscyplinarny. Będąc nadal częścią krytyki środowiskowej, poddaje ją zarazem sceptycznemu, ale i twórczemu oglądowi; można tę relację porównać do postmodernizmu, który bywał przecież interpretowany jako samoświadomość modernizmu, faza krytycznego oglądu nowoczesności.

Chciałabym na zakończenie omówić propozycje teoretyczne i praktyczne, mieszczące się w ramach dwóch zjawisk środowiskowych c z w artej fali: ekokrytyki materialnej (i jej znakomitej przedstawicielki Serenelli Iovino) i Timothy Mortona, który - mimo związków, jakie łączą go z materializmem ekologicznym - ustanawia oddzielną, autonomiczną jakość jako filozof i krytyk sztuki środowiskowej.

Pierwszy z wspomnianych nurtów jest przykładem jednego z „nowych materializmów", dokonujących twórczej i wielostronnej rekonceptualizacji pojęcia materii i jej pozycji w kulturowych praktykach. Występują one przeciwko radykalnej, poststrukturalistycznej „dematerializacji świata”. Przedstawiciele ekokrytyki po „zwrocie materialnym” zajmują się jednak materią specyficzną, istniejącą w niewiarygodnym splątaniu sił natury, dyskursów, ciał ludzkich i nieludzkich. Stacy Alaimo, Huberta Zapfa, Jane Bennett interesuje

45 K. Rigby, Earth's Poesy: Romantic Poetics, Natural Philosophy, and Biosemiotics, w: Handbook of Ecocriticism and Cultural Ecology, s. 46. 
to, jak materia świata bywa ucieleśniona w ludzkim doświadczeniu i ludzkim umyśle. Według Jane Bennett materia jest wypełniona utajoną sprawczością, która przybiera formę opowieści - „a storied matter" ${ }^{\text {"46, }}$, materii opowiedzianej, materii jako tekstu. Skoro materia jest tu rozpatrywana jako „miejsce produkcji i ucieleśnienia znaków" ${ }^{\text {"77 }}$, literaturoznawcy tropią miejsca, które są przez nich klasyfikowane jako „sploty procesów materialnych i dyskursywny$\mathrm{ch}^{\text {"48 }}$, bowiem, jak twierdzi Serpil Opermann, „literackie opowieści wynikają z interakcji pomiędzy ludzką kreatywnością a narratywizmem materii" ${ }^{49}$. Teksty literackie definiowane są tu jako „sploty sprawczości”, domagają się też specyficznych strategii lektury i interpretacji, którą Oppermann nazywa "czytaniem dyfrakcyjnym" ${ }^{50}$. Chodzi o to, by rozdzielane, wrogie sobie bieguny rygorystycznych dychotomii, którym przypisać można określone aspekty tekstu literackiego (dyskurs-materia, natura-kultura) nie były utrzymywane w separacji, przeciwnie, zdaniem ekokrytyków materialistycznych powinno się doprowadzić do sytuacji, w której wartości te „czytają (i weryfikują) siebie" wzajemnie.

Materialna krytyka środowiskowa na nowo definiuje podmiotowość, postrzegając ją jako fenomen, „wytwarzający się w starciu z «krajobrazami ryzyka», biologicznymi formami materii, strukturami władzy"51. Nacisk pada tu na dynamiczne produkowanie „ja” w sytuacji stałej nieprzewidywalności, katastrof klimatycznych, narastających nierówności cywilizacyjnych i ekonomicznych. Ekokrytyków c z w artej fali fascynują ekokatastrofy, zdegradowane cywilizacyjnie postnuklearne pejzaże dawnych poligonów atolu Bikini czy Nevada Test Site ${ }^{52}$, ogólnie zaś odpowiada im apokaliptyczne

S. Oppermann From Ecological Postmodernism to Material Ecocriticism. Creative Materiality and Narrative Agency, w: Material Ecocriticism, ed. by S. Iovino, S. Oppermann, Indiana University Press 2014, s. 714 .

S. Iovino Material Ecocriticism. Matter, Text, and Posthuman Ethics, w: Literature, Ecology, Ethics. Recent Trends in Ecocriticism, s. 52.

48 Tamże, s. 60.

49 S. Iovino, S. Oppermann Introduction: Stories Come to Matter, w: Material Ecocriticism, ed. by S. Iovino, S. Oppermann, Indiana University Press, Bloomington-Indianapolis 2014, s. 317. (ebook). Tamże, s. 252.

51 Tamże. Ch. Glotfelty Corporeal Fieldwork and Risky Art. Peter Goin and the Making of Nuclear Landscapes, w: Material Ecocriticism. 
zabarwienie narracji o świecie, które często podporządkowane są trajektorii przyszłościowej ${ }^{53}$.

Jak przebiega aplikacja omówionych wyżej teoretycznych założeń ekokrytyki materialnej? W udzieleniu odpowiedzi na to pytanie pomocna okaże się lektura artykułów i książek Serenelli Iovino, prominentnej przedstawicielki omawianego tu nurtu, autorki olśniewających interpretacji urbanistycznych narracji literackich i kulturowych. W swoich książkach Filosofie dell'ambiente: etica, natura, societa (2004) czy Ecologia litteraria: Una strategia di sopravvivenza (2006) traktuje ona miasto jako „kolektyw materialno-semiotyczny”, splot sprawczości klimatycznych, geologicznych, oceanicznych, kreacji człowieka (zawsze jednak ujmowanej w relacji do lokalnej historii naturalnej). Literackość/tekstualność pojmowana jest tu jako tropienie szczególnej „odmiany elokwencji, rozproszonej w materialnych formach świata". W artykule From Thomas Mann to Porto Marghera. Material Ecocriticism, Literary Interpretation, and Death in Venice ${ }^{54}$ Iovino zajmuje się Wenecją, próbując odpowiedzieć na pytanie, co jest specyficzną narracją tego miasta? Pisanie Wenecji to, jej zdaniem, „ćwiczenie z hybrydyczności”, bowiem o środowiskowej tożsamości tego miejsca decyduje zmieszanie lądu i wody, które tworzy nową jakość, nieredukowalną do cząstkowych składników. Wenecja leży we wnętrzu laguny, jej ekosystem tworzą unikatowe warunki ewolucyjne, zmieszanie dwóch konkurencyjnych żywiołów - wód rzecznych i oceanicznych, wywołujących rytm przypływów i odpływów, które tworzą specyficzną florę i intensywny zapach, osiadający na niestabilnych wyspach-,,amfibiach". Wprawdzie o Wenecji pisali znakomici twórcy od Szekspira, Simone Weil po Tomasza Manna i Passoliniego, jednak na ogół odczytywana ona była w izolacji od jej ekosystemu, z dala od uwarunkowań historii naturalnej. W ujęciu Iovino właściwie tylko Mannowi udało się wyczytać „subtekst, wytworzony przez dynamiczną ewolucję wody, lądu, klimatu, ekologii i historii" ${ }^{\prime \prime}$. W Śmierci w Wenecji miasto na lagunie odzyskuje swoją materialność,, ,cielesność,, poprzez użycie go w funkcji narracyjnej ramy dla historii o ludzkiej starości i śmierci, a zatem dzięki połączeniu perspektyw mikro- i makrologicznej. Dlatego też nowelę Manna czyta się jako „historię o ciałach, których makrokategorią jest ciało

Zob. S. Oppermann The Future of Ecocriticism. Present Currents, w: The Future of Ecocriticism. New Horizons. ed. by S. Opperann, U. Ozdag, S. Slovic, Cambridge Scolars Publishing 2011. and Death in Venice, w: Handbook of Ecocriticism and Cultural Ecology, s. 349-367. 
Wenecji jako organizm hybrydyczny i kolektywny"56. Punktem wspólnym łączącym dwa wymiary staje się motyw „ciał/cielesności” starzejących się, podlegających rozpadowi, niespójnych i w wieloznaczny sposób nieuposadowionych (mieści się w tej kategorii i problem nieheteronormatywności bohatera, i ścieranie się żywiołów Wschodu i Zachodu, natury i kultury, stałego i płynnego).

Jak widać, Serenella Iovino w sposób niezwykle inspirujący ogrywa w interpretacjach koncept „miasta jako ciała”. Sięga po niego również w artykule Bodies of Naples. Stories, Matter, and the Landscape of Porosity ${ }^{57}$. Motyw ciała wprowadzony zostaje już na początku, gdy autorka charakteryzuje znaną starożytną statuę, zwaną "Corpo di Napoli”, symbolicznie przedstawiającą losy miasta, zespalającą czasy zamierzchłe, kiedy to Neapol był siedliskiem greckim i moment zajęcia Neapolu przez wojska alianckie. Statua ta łączy wszystkie poziomy bytu: ciała ludzkie i nieludzkie, materialność miejsca, siły natury, które wchodzą w dynamiczną interakcję z dyskursami, sferą wyobraźniową, pamięcią. Drugą kategorią, która posłużyła włoskiej badaczce do opisu Neapolu, jest kategoria „porowatości”. Zdaniem Iovino, właśnie naprzemienność dziur i wypełnień charakteryzuje każdy element tkanki miejskiej. Porowatość oznacza również przepuszczalność, wprowadza zatem rys transformacji, przepływu energii, wielokulturowości. Neapol to miasto zbudowane z porowatego jasnożółtego piaskowca pochodzenia wulkanicznego, który łatwo ulega zwietrzeniu, korozji. Jest to miasto zbudowane z wulkanicznej materii i spoczywające na wulkanicznych skałach, leżące w pobliżu niepokojącego wulkanu i makabrycznej pozostałości po jego erupcji (Pompeje). Dominującym wymiarem istnienia Neapolu jest w odczytaniu Iovino telluryczność, a jego historią - postępująca mineralizacja tkanki miejskiej i jej kulturowego istnienia. Lawa i skały wulkaniczne, tworzące przekrój geologiczny, po którym stąpają mieszkańcy i turyści, stają się ucieleśnioną pamięcią (i zapomnieniem) o nieistniejących osadach, ich mieszkańcach, których "ciała” istnieją jako pustka, odcisk w zastygłej lawie wulkanu.

Timothy Morton chętnie przyznaje się wprawdzie do związków z ekologicznym materializmem, jednak stanowi zjawisko osobne, jako teoretyk niezwykle oryginalny, obdarzony charyzmatycznym (ale i karkołomnym)

56 Tamże, s. 358.

57 S. Iovino Bodies of Naples. Stories, Matter, and the Landscape of Porosity, w: Material Ecocriticism.... 
stylem myślenia i pisania ${ }^{58}$. W książce Ecology without Nature ${ }^{59}(2007)$ określa zaplecze teoretyczne swoich badań jako kombinację konceptów poststrukturalistycznych, zwłaszcza Derridiańskich, i dość na razie mglistych projektów lewicowej ekokrytyki, odcinającej się od konserwatywnych inspiracji Heideggerowskich, które tradycyjnie traktowały treść tekstu ekokrytycznego jako kruchą i cenną zawartość, zasługującą na zdeponowanie i ochronę. Konserwatywna ekologia - niczym patriarchalizm wykorzystujący kobiety w funkcji nośnika alegorii - czyni z Natury dwuznaczny fetysz, ubóstwia ją, czyni „obiektem sadystycznej adoracji” ${ }^{60}$, zarazem zapoznając jej istotę. Morton wpisuje się natomiast w ramy „ecocritique” Timothy Luke'a - metateoretycznego, autorefleksyjnego nurtu, zalecając porzucenie „ekologocentryzmu”, czyli samego konceptu/pojęcia Natury na rzecz poszukiwania wyznaczników środowiskowej e s te ty ki, bowiem, jak twierdzi amerykański ekokrytyk, tylko w obszarze niekognitywnym, antypojęciowym można uchwycić „ruchomą prawdę" o relacji człowieka ze środowiskiem.

Timothy Morton osnuwa swoją teorię środowiskową wokół dwóch pojęć: „ekomimesis” i poetyki auratycznej (ambient poetics). Obydwa pozostają wobec siebie w relacji fenotekstu i genotekstu (pojęcia Kristevej), wzorca, dominującej retoryki opisu natury i jej twórczego przekroczenia. „Ekomimesis” to „ideologiczna siatka wierzeń, praktyk (retorycznych), procesów skupionych wokół idei świata zewnętrznego" ${ }^{11}$ (i natury), stwarzająca iluzję autentyczności, czasu teraźniejszego (narracji i lektury), wyczerpywania bogactwa natury poprzez enumerację i tok parataktyczny. „Ekomimesis” wspomaga tworzenie fantazmatów natury, potocznych jej wyobrażeń, które pod pozorem troski o środowisko przemycają nastawienie antropocentryczne. Poetyka auratyczna natomiast twórczo "nacina” tę ustabilizowaną retorykę. Kwestionuje ona i znosi pęknięcie pomiędzy zawartością i obramowaniem tekstu, traktując jego umowne kontury jako przepuszczalną membranę, poprzez którą przepływają niespójne i zmienne jakości: semy, dźwięki, rytmiczne wibracje,

58 Greg Garrard konsekwentnie, ale też nadzwyczaj jednostronnie sytuuje dorobek Timothy Mortona na tle dekonstruktywizmu, tropów Derridiańskich, zwłaszcza kultu czytania, lektury świata i tekstu literackiego. Zob. G. Garrard Introduction, w: The Oxford Handbook of Ecocriticism, s. 14 .

59 T. Morton Ecology without Nature. Rethinking Environmental Aesthetics, Harvard University Press 2007.

60 Tamże, s.5.

61 Tamże, s. 33. 
amplitudy, tonacje barwne. W ten sposób tekst literacki i jego analiza (tak, jak analiza wiersza Denisa Levertova To the Reader, przeprowadzona przez Mortona w pierwszym rozdziale Ecology without Nature) stają się nieoczywistym ekwiwalentem świata natury, procesów ewolucji, zmian w biosferze i jakości ekosystemów. Tak rozumiana literatura ekologiczna oddaje sprawiedliwość naturze niejako negatywnie, podobnie jak teologia apofatyczna, unikając tym samym pułapek estetycznego kiczu i fetyszyzmu. Byłaby to jedna $\mathrm{z}$ form uprawiania stylistyki "naturalizmu drugiego stopnia”, opisywania „drugiej natury”, które postulował Th.W. Adorno, jeden z intelektualnych mentorów Mortona.

W kolejnych książkach pomysły teoretyczne Timothy Mortona ulegają radykalizacji i uekscentrycznieniu. Dzieje się tak w dużej mierze dzięki narastającej interdyscyplinarności jego warsztatu, wyjściu poza literaturoznawstwo w kierunku teorii kultury, krytyki sztuki, nauk o życiu. W DarkEcology ${ }^{62}$ (2016) przybierają na sile tony apokaliptyczne, nakaz nadawania myśli środowiskowej bardziej mrocznego, dekadenckiego wydźwięku. Postulowana „ekognoza” ma w zamyśle Mortona łączyć barokową ozdobność, „feeryczność” myślenia i pisania z nowym nihilizmem w duchu Nietzschego, czytanego przez Heideggera - czyli z myśleniem o świecie, ogarniętym globalnym ociepleniem z wnętrza katastrofy, z pełną świadomością tego, że żyjemy w społeczeństwie ryzyka (risk society Ulricha Becka), w świecie, zdominowanym przez nieintencjonalne, nieprzewidywalne konsekwencje naszych działań. Jako antidotum na ten apokaliptyczny stan świadomości Morton zaleca pisanie „arche-lityczne" i myślenie o świecie w kategorii „hiperobiektów”.

Arche-lityczność to czasowość sprzed neolitu, sprzed agrokultury, która podbiła środowisko i doprowadziła do ekologicznej katastrofy; ujawnia się ona w zgodzie na istnienie zjawisk niekontrolowalnych, odbierających człowiekowi pozycję dominującą. Dochodzi do głosu w dystopiach fantastyczno-naukowych, horrorach, opowieściach gotyckich, fotografiach i filmach, przywołujących zjawiska paranormalne. Wedle Mortona arche-lityczność odsłania się w charakterystycznym błysku, lśnieniu pisania literackiego i krytycznego niektórych autorów, które stanowi swoistą nadwyżkę estetyczną, nie pozwala się zracjonalizować, nie podlega metodologicznej falsyfikacji.

W Hyperobjects ${ }^{63}$ Morton jeszcze dalej przesuwa granice eksperymentowania z językiem ekologicznego literaturoznawstwa. Rezygnuje z przywilejów

62 T. Morton Dark Ecology. For a Logic of Future Coexistence, Columbia University Press 2016.

63 T. Morton Hyperobjects. Philosophy and Ecology after the End of the World, University of Minnesota Press 2013. 
metajęzykowego pisania, bowiem rozwijana przez niego teoria hiperobiektów zakłada istnienie badacza wewnątrz przedmiotu naukowego opisu, egzystencjalną „lepkość” wobec niego, zniszczenie dystansu podmiot-przedmiot. Świat, opisywany w kategorii hiperobiektów - którymi są jakości ponadlokalne, nieuposadowione, długowieczne: zarówno system solarny, jak i niezniszczalne plastikowe torebki, materiały nuklearne i biosfera - wypełnia lepka plątanina (mesh) różnorodnych bytów. Ilustracją części teoretycznej książki są analizy instalacji, które Morton uznaje za reprezentacje „sztuki hiperobiektów" (prace Tary Donovan Unititled, Christa Wainwrigtha Red Ice 3). Opierają się one na przeświadczeniu, że ludzie i ich wytwory są „opakowane" w hiperobiekty, które są opakowane w kolejne hiperobiekty (itd.). Sztuka ta operuje motywami zanikania, zależności, powiązań różnych materiałów i gatunków, zanurzenia (obrazów w wodzie).

Morton nazywa sztukę hiperobiektów „sztuką intymności”"64 i używa tego określenia jako postulatu wobec ekologii jako formacji interdyscyplinarnej. Zdaniem autora Hyperobjects, ekologia i krytyka środowiskowa powinny być naukami o intymności, o tym, w jak wielkiej bliskości wobec siebie egzystują ludzie i zwierzęta, czynniki klimatyczne i hałdy śmieci. Estetyką, pomocną w formułowania tego przekazu nie powinna być jednak retoryka, przesiąknięta ideologią, lecz, przeciwnie, denaturalizacja Natury, jej krytyczny, autorefleksyjny opis.

64 Tamże, s. 139. 


\section{Abstract}

\section{Aleksandra Ubertowska}

UNIVERSITY OF GDAŃSK

'Speaking in the Name of the Biotic Community': Anatomies and Theories of the Environmental/Ecological Text

This is a meta-theoretical and meta-disciplinary study on the achievements of ecocriticism and environmental criticism, from the first wave of ecocriticism to the most recent trends, such as material ecocriticism and Timothy Morton's theories rooted in deconstruction. Ubertowska devotes particular attention to the concept of the 'environmental text' developed by Lawrence Buell, the Nestor of the discipline. His concept forms the axis of this review of different positions within ecocriticism and environmental criticism.

\section{Keywords}

ecocriticism, environmentalism, materialism, hyperobjects 